\title{
The Imposition of Sanctions for Children
}

\author{
Rafika Nur1* ${ }^{*}$ Handar Subhandi Bakhtiar ${ }^{2}$ \\ ${ }^{1}$ Faculty of Law, Ichsan Gorontalo University, Indonesia. \\ 2 Faculty of Law, Hasanuddin University, Indonesia. \\ * Corresponding author's e-mail: rafikanur290785@gmail.com
}

\begin{tabular}{l} 
ARTICLE INFO \\
\hline Keywords: \\
Criminal Law; Children; \\
Sanction; Criminal Justice \\
System \\
How to cite: \\
Nur, R., Bakhtiar, H.S. \\
(2020). "The Imposition of \\
Sanctions for Children," \\
Hasanuddin Law Review, 6 \\
(2): 165-171 \\
DOI: \\
10.20956/halrev.v6i2.2493 \\
\hline
\end{tabular}

\begin{abstract}
In the children criminal justice system in Indonesia, there are two systems of sanctions namely criminal sanctions and sanctions actions. A child who commits a criminal offense may be subject to criminal sanctions or sanctions. Imposing sanctions for children becomes something oriented towards coaching and protecting children. However, the imposition of sanctions for children can not be effective because of conflicting legal rules, law enforcement officials who have different paradigms in guarding the legal process against children, facilities and infrastructure that are incomplete and inadequate, making it difficult to enforce sanctions on children as well as the poor stigmatization of society against children in conflict with the law.
\end{abstract}

Copyright $@ 2020$ HALREV. All rights reserved.

\section{Introduction}

One of the goals of the existence of law is to realize the value of justice, for that law must reflect justice. ${ }^{1}$ Ideally, the process of law enforcement must uphold justice for everyone. In order to realize these national goals, national development efforts are needed which include full human development. One such effort is development in the field of law, especially criminal law.

Law can not be seen as something final (finite scheme), but the law must continue to move, change and follow the dynamics of human life. Therefore, the law must be explored through progressive efforts ${ }^{2}$ namely by presenting a breakthrough or

\footnotetext{
1 Koller, D. S., \& Eckenfels-Garcia, M. (2015). Using Targeted Sanctions to End Violations Against Children in Armed Conflict. BU Int'l LJ, 33, 1.

2 Rahardjo, S. (2010). Penegakan Hukum Progresif. Jakarta: Kompas.p. 1
} 
improvement in the law itself can even change the totality of the legal system towards a better and truly to reach the truth and achieve the goal of justices.

In the context of criminal law enforcement, as an effort to achieve justice can be implemented one of them by way of preventing and overcoming a crime that is part of a criminal policy ${ }^{4}$. The policy was carried out using criminal law facilities (Penal Facilities), especially at the judicial policy stage (In-Abstracto) to the applicative stage and the execution stage (In-Concreto Criminal Law Enforcement). Ideally, at each stage, attention must be paid to and lead to the achievement of the national goals of the Republic of Indonesia as stipulated in the Preamble of the 1945 Constitution of the Republic of Indonesia (NRI), namely to realize equitable justice for all Indonesian people.

The Indonesian Constitution provides guarantees for children's rights specifically as affirmed Article 28 B paragraph (2) of the 1945 Constitution of the Republic of Indonesia which states that every child has the right to survival, growth and development and is entitled to protection from violence and discrimination. Article 28 D paragraph (1) Every person has the right to recognition, guarantee, protection and legal certainty that is just and equal before the law. With this provision, the State has an obligation to provide legal protection in the justice system, including children of criminal offenses.

The development of criminal law in Indonesia is realized through the enforcement of criminal law which operates operationally through a system called the Criminal Justice System. ${ }^{5}$ According to Article 28B paragraph (2) of the 1945 Constitution, children have constitutional rights that must be guaranteed and protected and fulfilled. Thus, the existence of children is not just a subject that is a private matter or domestic or family affairs, but also included in state affairs. To measure the extent to which a type of criminal sanction can meet the objectives of punishment determined by the criminal law system concerned. This is because the criminal nature is only a "tool" to achieve the goal. Various theories of punishment that emerged in his era have formulated different objectives of punishment. ${ }^{6}$

Regarding sanctions for actions, Roeslan Saleh stated that if the criminal in an effort to achieve the goal is not solely by imposing a crime, but in addition it also uses action. So, in addition to the criminal sanctions there are also actions. This is aimed solely at special prevention. The purpose of this action is to safeguard the security of the people against people who are a bit dangerous and will commit criminal acts. ${ }^{7}$

3 Justice comes from the word fair which means impartial or balanced, it can also mean taking sides with the right or influencing the truth and not doing anything arbitrarily. Justice was first interpreted by the Roman legal expert Uipianus "tribure jus suum cuique" which means giving based on their respective rights. Schopenhauer argues that justice is the principle of neminem leadere, which is the principle of avoiding actions that cause suffering, loss and pain for others. Dennis Lloyd said that justice and truth are virtues.

4 Dey Ravena and Kristian. (2017). Kebijakan Kriminal (Criminal Policy). Jakarta: Penerbit Prenadamedia Group. p 3

5 R. Wiyono. (2016). Sistem Peradilan Pidana Anak di Indonesia. Jakarta: Penerbit Sinal Grafika. p. 132.

6 The Use of Criminal Theory Can Be Seen In Judges' Considerations, Namely Against Severe Relatively Serious Crimes, Prevention Of Penalty Containing Elements Of Retaliation, Whereas In Relatively Mild Crimes, Criminal Purposes Can Be Emphasized To Personal Actors For Resocialization. See: Kholiq, M.A. and Wibowo, A. (2016). "Penerapan Teori Tujuan Pemidanaan Dalam Perkara Kekerasan Terhadap Perempuan: Studi Putusan Hakim" Jurnal Hukum Ius Quia Iustum, 23 (2): 197-203.

7 Cammett, A. (2006). Expanding collateral sanctions: The hidden costs of aggressive child support enforcement against incarcerated parents. Geo. J. on Poverty L. E Pol'y, 13, 313. 
Sanction of actions aimed at the perpetrators of criminal acts based on protection, so that the perpetrators of criminal acts will be better and not solely for the purpose of retaliation. Actions are also oriented forward, so that the perpetrators try to better understand that what was done is not right and violates the law, so that one day they will not repeat it. According to HL Packer about sanction actions, "The Primary Purpose Of Treatment Is To Benefit The Person Being Treated. The Focus Is Not On His Conduct, Past Or Future, But On Helping Him. ${ }^{8}$

Substantially, the types of sanctions for action in child criminal law in Indonesia are still limited, both the types and variations of threats. Even systematics and types of actions are still simple. The dysfunction of supervising judges and observers regarding the supervision of the implementation of sanctions for actions against children is also evidence of the non-functioning sanctions system for children in an optimal way. A series of mistakes by some judges in imposing sanctions on children can also be evidence of the imperfectness of the sanctions system of action in child criminal law in Indonesia. ${ }^{9}$

The issue of child development is one of the most important things. The state as a place of refuge for its citizens must provide regulations guaranteeing protection for real children. Still remembering in 2005-2006, public attention was sucked up on the problem of an elementary school student from North Sumatra who had to go to trial many times due to his beating his schoolmates. Apparently the Raju case is not the first and the last Steven Allen report ${ }^{10}$ states that more than 4,000 Indonesian children are brought to justice each year for the crimes they have committed.

Research conducted by ICJR found that the use of imprisonment was still quite high. Child detention is still very high, children who enter the trial process are generally detained and leave only $7 \%$ of children related to the law and not detained. The rest of the data that can be identified, children must be subject to detention. Although there is a possibility of the detention of a child being suspended, not many Parents or Guardians use the detention hold for children. The use of detention or deprivation of physical freedom should be the last remedy for children in connection with the law. Hence, it needs to be clarified in the rules of the children criminal justice system regarding the sanction of action against children so that in the case of imposing a judge's sentence it can be objective in deciding the cases of the child.

\section{Method}

This research is a combination of normative legal research and empirical legal research that is used to answer problems that are formulated by searching documents related to the focus of the problem under study. ${ }^{11}$ The data obtained from the study, then described in accordance with the main problems that were studied in a descriptive qualitative.

8 Herbert L. Packer. (1968). The Limits Of The Criminal Sanction, Calofornia: Stanford University Press. p. 25 .

9 Sutatiek, S. (2013). Rekonstruksi Sistem Sanksi dalam Hukum Pidana Anak di Indonesia. Yogyakarta: Aswaja Pressindo. p 83

10 Allen, S. (2003). Kata Pengantar Dalam Purnianti, Mamik Sri Supatmi Dan Ni Made Martini Tinduk, Analisa Situasi Sistem Peradilan Pidana Anak (Juvenile Justice Sistem) Di Indonesia, Unicef Indonesia. p. 1

11 Marzuki, P.M. (2005) Penelitian Hukum. Jakarta: Prenadamedia Grup. p.133 


\section{Results}

This section is the most important section of your article. The analysis or results of the research should be clear and concise. The results should summarize (scientific) findings rather than providing data in great detail. Please highlight differences between your results or findings and the previous publications by other researchers. Based on data from the Ministry of Law and Human Rights, the number of child cases during 2015-2019 can be described as follows:

Table 1. Number of Children Cases in 2015-2019

\begin{tabular}{cccccccc}
\hline Year & $\begin{array}{c}\text { Diversity, } \\
\text { Turned To } \\
\text { Parents }\end{array}$ & $\begin{array}{c}\text { Diversity, } \\
\text { To Social } \\
\text { Institutions }\end{array}$ & $\begin{array}{c}\text { Decision, } \\
\text { Turned To } \\
\text { Parents }\end{array}$ & $\begin{array}{c}\text { Decision, } \\
\text { To Social } \\
\text { Institutions }\end{array}$ & $\begin{array}{c}\text { Verdict, } \\
\text { Criminal } \\
\text { Conditional }\end{array}$ & $\begin{array}{c}\text { Verdict, } \\
\text { Imprisonment }\end{array}$ & Total \\
\hline 2015 & 303 & 14 & 30 & 16 & 21 & 183 & $\mathbf{5 6 7}$ \\
2016 & 3223 & 248 & 320 & 335 & 284 & 2138 & $\mathbf{6 5 4 8}$ \\
2017 & 4102 & 277 & 432 & 563 & 344 & 3639 & $\mathbf{9 3 5 7}$ \\
2018 & 3247 & 273 & 343 & 702 & 349 & 2083 & $\mathbf{6 9 9 7}$ \\
2019 & 1411 & 153 & 172 & 305 & 234 & 978 & $\mathbf{3 2 5 3}$ \\
\hline
\end{tabular}

Source: Indonesian Ministry of Law and Human Rights Data, 2020.

Based on the table above, it appears that during 2015 to September 29, 2019 the number of children who were confronted with the law nationally was 26,722 children, out of that total, the highest number of children who faced the law in 2017 was 9,357 children. Various attempts were made by the government and law enforcement officials in handling cases of children in conflict with the law. These efforts as part of the protection of children's rights in conflict with the law. Diversion is one form of protection for children in conflict with the law.

Since the enactment of Government Regulation Number 65 Year 2015 concerning Guidelines for the Implementation of Diversity and Handling of Children Not Aged 12 (Twelve Years) and enacted by the government on August 19, 2015 has had a significant influence on the reduced number of children being brought to justice and decided by judge through imprisonment and conditional conviction. This can be seen in the diagram above, where from the total number of children in conflict with the law were 26,722 children from 2015 to 29 September 2019, through the sentences of prison and conditional criminal court totaling 10,253 children or $38.37 \%$. While from the total number of children in conflict with the law as many as 26,722 children from 2015 to 29 September 2019, the number of children in conflict with the law committed by diversion was returned to parents by 12,286 children or $45 \%$ and as many as 965 children by child diversion. submitted to social or other institutions.

The degree of legal effectiveness according to Soerjono Soekanto, is determined by the level of community compliance with the law, including law enforcers, so that the assumption is known that, "a high level of compliance is an indicator of the functioning of a legal system. And the functioning of the law is a sign that the law has achieved the legal goal of trying to defend and protect the community in the association of life. ${ }^{12}$

12 Nobile, J. J. (2015). Adoptions gone awry: Enhancing adoption outcomes through postadoption services and federal and state laws imposing criminal sanctions for private internet rehoming. Family Court Review, 53(3), 474-486. 
In this paper, legal factors or laws are very influential in the effective implementation of the SPPA Law. According to Purba and Soerjono Soekanto ${ }^{13}$ Law in the material sense is a written regulation that is generally accepted and made by the central and regional authorities. Law in the material sense is a written regulation that is generally accepted and made by the Central and Regional Authorities.

Law Number 11 of 2012 concerning the Children Justice System (SPPA Law) is a law that replaces the enactment of Law Number 3 of 1997 concerning Children Courts. There are many changes that occur between the two laws from the substance of the law, legal structure to the legal culture that must be built and understood by both law enforcement officials and the general public. Even though the SPPA Law was formed in 2012, the new law came into force in 2014. The validity of the SPPA Law which has entered the year 2 years there are still several obstacles that hamper its effectiveness in its implementation.

The term law enforcement is very broad, because it includes those who directly and indirectly engage in the field of law enforcement. Sociologically law enforcement has a status (status) and role (role). (Social) position is a certain position within the social structure, which is high, moderate or low. Therefore, someone who has a certain position, usually called a role occupant (role occupant). Law enforcement is the process of making efforts for the establishment or functioning of legal norms as a real guide to behavior in traffic or legal relations in the life of society and the state. In terms of the subject, law enforcement can be done by a broad subject and can also be interpreted as law enforcement efforts by the subject in a limited or narrow sense.

In order to enforce the applicable legal rules, it is necessary to have a state institution called judicative power. ${ }^{14}$ Upholding justice is not just carrying out formal procedures in the legal regulations in force in a community, at least that is a statement that is often coined by Mahfud MD, that upholding the values of justice is more important than just carrying out various formal legal procedures that are often associated with law enforcement. 15

For this reason, in the stage of law enforcement in Indonesia, the presence of law enforcers with a vision of justice and rulers who are fair is needed, as in the traditional legal ideals of the Indonesian people termed "the queen of justice" or as dreamed by the great Greek philosopher, namely Plato with the concept of a "philosophical king" (philosophers king) thousands of years ago. ${ }^{16}$

In accordance with Table 1 on page 182 which gives an overview of the number of children in conflict with the law, it can be illustrated that the total number of children in conflict with the law was 26,722 children from 2015 to 29 September 2019, through the sentencing of prison and conditional criminal trials of 10,253 children or by $38.37 \%$. Whereas out of the total number of children in conflict with the law as many as 26,722 children from 2015 to 29 September 2019, there were children who were sanctioned with actions totaling 3,218 children or $12.04 \%$, details of the form of action sanctions imposed on children in the form of children returned to parents and sanctions for actions in the form of children being handed over to social institutions or others.

13 Soekanto, S. (2014). Faktor-Faktor Yang Mempengaruhi Penegakan Hukum. Jakarat: Rajagrafindo Persada. p.11

14 Sutiyoso, B. (2010). Reformasi Keadilan Dan Penegakan Hukum Di Indonesia. Yogyakarta: UII Pres. p.3

15 Ibid. p. 4

16 Fuady, M. (2013). Teori-Teori Besar (Grand Theory) Dalam Hukum. Jakarta: Penerbit Prenadamedia Group. p. 53 
The lack of children who are dealing with laws that are sanctioned by action through a court decision is due to a conflicting norm ${ }^{17}$ as described earlier, so that more children who are faced with the law are sentenced to imprisonment or conditional criminal. Conflict of norms as outlined above causes law enforcement officers to continue to use the old paradigm in the settlement of child crime, namely the imposition of criminal sanctions. Apart from the interests of law enforcement officers in fighting for the interests of victims of criminal acts and maintaining public order, but when seeing clearly the birth of Law no. 11 of 2012 concerning the Child Criminal Justice System which prioritizes protection ofthe dignity of children in the criminal justice system through special protection. One form of special protection referred to is the handling of cases of children dealing with the lawbased on the roles and duties of the community, government, and other state institutions that have the obligation and responsibility to improve children's welfare.

\section{Conclusion}

The implementation of law enforcement in the imposition of sanctions for children has not been realized optimally, it can be seen from: Legal aspects, the absence of optimal protection of children in the juvenile justice system due to conflict of norms related to the imposition of sanctions for actions with criminal sanctions. In terms of law enforcement, the suboptimal realization of child protection in the juvenile justice system occurs because the paradigm of law enforcement officials is still more likely to impose criminal sanctions on children than action sanctions. In terms of facilities, the lack of facilities in the form of LPKA in Indonesia has led to the fact that there are still children undergoing convictions in correctional institutions that are combined with adult fostered citizens. Community aspects, there is still community stigmatization of children in conflict with the law so that community understanding is needed so that children can be re-accepted within the community. As a suggestion, especially to the Government, it is expected to realize child protection through the addition of facilities that support the implementation of sanctions measures in the form of additional LPKS in some regions.

\section{References}

Allen, S. (2003). Kata Pengantar Dalam Purnianti, Mamik Sri Supatmi Dan Ni Made Martini Tinduk, Analisa Situasi Sistem Peradilan Pidana Anak (Juvenile Justice Sistem) Di Indonesia, Unicef Indonesia.

Cammett, A. (2006). Expanding collateral sanctions: The hidden costs of aggressive child support enforcement against incarcerated parents. Geo. J. on Poverty L. $\mathcal{E}$ Pol'y, 13, 313.

Fuady, M. (2013). Teori-Teori Besar (Grand Theory) Dalam Hukum. Jakarta: Penerbit Prenadamedia Group.

17 There is an overlap between the provisions in Article 69 paragraph 2 and Article 82 paragraph 3. Where Article 69 paragraph 2 regulates the age limitation of children who can be sanctioned in action while in Article 82 paragraph 3 regulates that related to children can only be subject to action except for criminal acts which are threatened with the threat of punishment above 7 years in prison. 
Herbert L. Packer. (1968). The Limits Of The Criminal Sanction, Calofornia: Stanford University Press.

Kholiq, M.A. and Wibowo, A. (2016). "Penerapan Teori Tujuan Pemidanaan Dalam Perkara Kekerasan Terhadap Perempuan: Studi Putusan Hakim" Jurnal Hukum Ius Quia Iustum, 23 (2): 197-203.

Koller, D. S., \& Eckenfels-Garcia, M. (2015). Using Targeted Sanctions to End Violations Against Children in Armed Conflict. BU Int'l LJ, 33, 1.

Marzuki, P.M. (2005) Penelitian Hukum. Jakarta: Prenadamedia Grup.

Nobile, J. J. (2015). Adoptions gone awry: Enhancing adoption outcomes through postadoption services and federal and state laws imposing criminal sanctions for private internet rehoming. Family Court Review, 53(3), 474-486.

Rahardjo, S. (2010). Penegakan Hukum Progresif. Jakarta: Kompas.

Ravena, D., and Kristian. (2017). Kebijakan Kriminal (Criminal Policy). Jakarta: Penerbit Prenadamedia Group.

Soekanto, S. (2014). Faktor-Faktor Yang Mempengaruhi Penegakan Hukum. Jakarat: Rajagrafindo Persada.

Sutatiek, S. (2013). Rekonstruksi Sistem Sanksi dalam Hukum Pidana Anak di Indonesia. Yogyakarta: Aswaja Pressindo.

Sutiyoso, B. (2010). Reformasi Keadilan Dan Penegakan Hukum Di Indonesia. Yogyakarta: UII Pres.

Wiyono, R. (2016). Sistem Peradilan Pidana Anak di Indonesia. Jakarta: Penerbit Sinal Grafika.

\section{Conflict of Interest Statement:}

The author(s) declares that the research was conducted in the absence of any commercial or financial relationships that could be construed as a potential conflict of interest.

Copyright $@ 2020$ HALREV. All rights reserved. 